Monica Heller*

\title{
Sociolinguistic frontiers: Emancipation and equality
}

https://doi.org/10.1515/ijsl-2020-2090

\begin{abstract}
In her conclusion to this issue, Monica Heller reflects on the ways in which the field has both advanced and obscured understandings of how linguistic inequality is related to broader hierarchies of power. The great accomplishment of sociolinguistics - its liberal and scientific claims that all languages are equal in value - did little to engage how inequalities between different groups of speakers were reproduced. Heller argues that the scholarly techniques for measurement and commensuration that allowed the formal comparison of language has neglected to ask how language "continues to serve as a terrain for the making of social difference and social inequality." She concludes with thoughts for how future sociolinguistics agendas might address this gap.
\end{abstract}

Keywords: sociolinguistics, engagement, (in)equality, emancipation

Since the institutionalization of sociolinguistics in the United States in the 1960s and 1970s, a process I described in the introductory essay, there have been both continuities and discontinuities in the field. Over the past year, a number of authors (mainly US-based) have explored both in this issue. I will close the series here by raising a few questions about what might be emerging as priorities, or at least important areas of inquiry, 50 years later. Against the linear progress model - as exemplified by the SSRC's Committee on Sociolinguistics - which dominated, and still dominates, the narrative of the field's "origins" and "development," scholars may be better served by understanding the salience of "language" in the context of cycles of capitalism and the struggles for emancipation and equality as responses to this context.

\footnotetext{
*Corresponding author: Monica Heller, University of Toronto, Toronto, Canada, E-mail: monica.heller@utoronto.ca
} 


\section{Liberal understandings of linguistic inequality: Expert knowledge and systems of measurement}

These two themes - emancipation and equality - were central to the range of sociolinguistic projects as they emerged in the period of decolonization and international development during the Cold War (whether those projects fell within the frame of what have been called ethnography of communication, variationist sociolinguistics, linguistic anthropology, or the sociology of language). They were understood in a positivist way, that is, they would be realized by the application to "real-world problems" of neutral, objective, scientific descriptions, aimed, in this case, at showing that differences in linguistic form and practice need to be understood as equal in value. Generally, positivist science (in this case linguistic science) holds that because phenomena can be subsumed within one overarching system of measurement, they are also intelligible within a single system of values. Therefore, the argument goes, linguistic variation is not hierarchical, because it can be described using a putatively universal system of description, in keeping with a liberal vision of multiculturalism (and multilingualism) in which differences are not radical or hierarchical.

In the case of sociolinguistics, this meant a somewhat paradoxical reproduction of the claims of linguistics against which sociolinguistics argued: as with any system of measurement, linguistic description both creates the phenomena it describes and measures, and produces "problematic" phenomena, that is phenomena understood to be problematic because they do not fit within the system. To the extent that both so-called "prescriptive" (normative, standardizing) and "descriptive” linguistics argued for a universal, uniform system of rules, they drew attention to linguistic matter that did not fit; It is precisely this matter that has been the core concern of sociolinguistics. At the same time, sociolinguistics sought similar kinds of objective and generalizable models and theories, and a similar position of detached expertise.

\subsection{Commensuration and regimentation}

Scholars working on translation (notably William Hanks in his 2010 study of the work of Franciscan missionaries in the Yucatan) have pointed out that fitting linguistic form into one system of measurement (Hanks calls this "commensuration"), while usually understood as resting on universal and 
neutral principles of description, can be seen instead as the construction of a frame of reference for understanding the world, which produces power effects. The desire for commensuration usually stems from specific unequal interests (in the case described by Hanks, religious conversion in the cause of imperialism). Even if, as Hanks also argues, the process is often dialectic, affecting both parties, the resulting distribution of resources, or the purposes for which commensuration is harnessed, often enhance inequality. The development of a regime of linguistic description may well have opened the door to specific understandings both of "Maya" and of "Spanish," but it was also part of a toolbox of modes of conquest. And, it forms part of the systems of linguistic measurement that we use to this day.

To better understand these systems of description, Bonnie McElhinny and I have talked about them as techniques of regimentation as well as legitimizing discourses (Heller and McElhinny 2017). Techniques of regimentation not only make sure that linguistic material is understood to be structured fundamentally the same way, They also make it possible to mask, in the Bourdieuian sense (Bourdieu 1982), how and why such linguistic material might be hierarchically valued (as was the case for much of the time). Or, with the rise of the welfare state, why the hierarchy of values in different linguistic forms and practices ought to be construed as illegitimate - as outside the realm of scientific practice. This, flattening of value, as Bourdieu argues, can have the perverse effect of contributing to the reproduction of that hierarchy.

This is the core problem of sociolinguistics as we have inherited it. By constructing all linguistic form and practice as universally commensurate, it was possible to both push back against racial and evolutionary hierarchies in the name of Reason and Equality, and simultaneously marginalize the problem of observable value hierarchies. Sociolinguistics has struggled to explain why such value hierarchies persist when the of arguments in support of them have no scientific basis. The problem has thus been consigned to the realm of individuals' prejudices to be eradicated via education. Questions of value hierarchies have largely remained on the periphery of the field, rather than being placed at the center of what scholars need to address if we want to take emancipation and equality seriously.

\subsection{Legitimization}

Underlying techniques of regimentation is the reproduction of the principles of categorization and hierarchization. Put differently, this reproduction legitimizes 
the social categories that are constructed to justify the unequal distribution of resources at the heart of relations of power. Racialization, feminization, sexualization, and infantilization of the other bundle the semiotic resources that have emerged from the long and complex history of capitalism and colonialism. These categories are arguably the key means we have developed to put social difference in the service of making social inequality. They underlie the categories of "us" and "other," the boundary across which commensuration must be made in order for some to accumulate and others to either serve the process of accumulation or be removed from that process.

Race, gender, class, sexuality, all have been at the heart of the ideology of the nation, with whiteness, masculinity, middle and upper class, and heteronormativity all embedded as the signs of who legitimately sets the rules of the game. By definition then, the language of the educated and male middle/upper class - the definers of the nation and its uniformized, regimented language becomes the standard against which other languages and language variants are made intelligible as substandard. Indeed, often the other is made intelligible as a certain form of unintelligibility (argot, jargon, childish, primitive, the list is quite long).

If emancipation from this regime of truth has long been understood as a core aim of sociolinguistics, this emancipation has not reckoned with why these categories are relevant ones. Instead, what we have is a form of identity politics that seeks to validate recognition of the language of the stigmatized other: the language of women, of Black Americans, of Indigenous peoples, of Latinx in the United States, or of beur in France (or of Kiezdeutsch in Germany or of Rinkeby Swedish in Sweden). The same dynamics of recognition is evident regarding standard, national languages (or nationalitaire "minority"/"minoritized" languages, like Catalan, Breton, or Tibetan), for whose speakers nation-state autonomy is claimed. ${ }^{1}$

Of course, these named language varieties, while the product of specific sociohistorical process, have social reality, and therefore material effects on their speakers. Yet, sociolinguistics has rarely examined how this social reality works systemically, preferring largely to defend the rationality of the language of the stigmatized other instead of studying historically contingent and semiotically substantive modes that establish linguistic hegemony, as well as how particular techniques of regimentation inscribe populations into the same (commensurable) frame, disregarding who actually benefits. Why those social

1 By nationalitaire, I mean understood through the principles of the nation, as the normal, natural or in any case desired frame of reference to be applied. 
categories, why there, why now (or then)? In other words, these social realities these sociolinguistic realities - need to be understood as forms of social organization, which are productive and reproductive of particular relations of inequality; the question is both how and why. We need to understand, for example, why emancipation has really only been imagined in the form of nation-state-type sovereignty.

\section{New sociolinguistic priorities}

Rather than assuming its relevance, linguistic scholars ought to ask why "language" has served, and continues to serve, as a terrain for the making of social difference and social inequality at all, and why in the forms that it has. I have argued above that one explanation lies in its function as a technique of regimentation and a legitimizing discourse. Further examination would allow us to better identify what is at stake for differentially positioned social actors in the conditions in which they find themselves, and which they contribute to producing. This approach distances us from the modernist model of linear progress, which underlies our field, and asks us instead to inquire what emancipation and equality might look like, for whom, when, and where.

Finally, there is the question of the two parts of the term "sociolinguistics." Part of that nationalitaire sovereignty has depended on the separation of population and language, of "socio" and "linguistics." Despite recent efforts to take on embodiment and social practice, we still use tools (techniques of regimentation) that allow us to treat language as an autonomous field. There are material reasons for this; among others, giving that up means giving up control over an area of expertise, along with its training programs, grant competitions, and research centers. At the same time, though, relativizing the autonomy of "language" potentially opens up new realms of inquiry, which allow for recentering the communicative dimensions of social process as part of understanding more broadly how social process works and what it produces - not just something that "linguists" ("sociolinguists," "linguistic anthropologists") do, over there, somewhere. Perhaps the project of emancipation and equality under contemporary conditions requires some thinking about what "language" does for us all, now. 


\section{References}

Bourdieu, Pierre. 1982. Ce que parler veut dire. Paris: Fayard.

Hanks, William. 2010. Converting words: Maya in the age of the cross. Berkeley, Los Angeles: University of California Press.

Heller, Monica \& McElhinny. Bonnie. 2017. Language, capitalism, colonialism: Toward a critical history. Toronto: University of Toronto Press.

Article note: This essay was originally published in Items: Insights from the Social Sciences, a publication of the Social Science Research Council. Heller, Monica. "Sociolinguistic Frontiers: Emancipation and Equality." In "Sociolinguistic Frontiers." Series, Items: Insights from the Social Sciences.https://items.ssrc.org/sociolinguistic-frontiers/sociolinguistic-frontiers-emanci pation-and-equality/. Reprinted with permission. 